\title{
Congestion Management in Deregulated Power System using Adaptive Moth Swarm Optimization
}

R Ramaporselvi ( $\square$ rramaporselvi@gmail.com )

Anna University Chennai

G. Geetha

Jerusalem College of Engineering

Keywords:

Posted Date: March 24th, 2021

DOl: https://doi.org/10.21203/rs.3.rs-343133/v1

License: (c) (i) This work is licensed under a Creative Commons Attribution 4.0 International License.

Read Full License 


\section{Abstract}

The authors have requested that this preprint be removed from Research Square. 